\title{
History, scale and the political ecology of ethical diamonds in Kugluktuk, Nunavut
}

\author{
Kolson Schlosser ${ }^{1}$ \\ Slippery Rock University, USA
}

\section{Introduction}

Arctic Canada plays a complex and varied role in the geographic imaginary of North Americans, ranging from debates about the assertion of northern Canadian sovereignty, to climate change vulnerability, to 'wilderness' as a cultural construct central to national identity, to the source of minerals and other raw materials for the more densely populated South. The latter issue rests upon core-periphery relations within a North American regional economy. One recent development in this regard has been the proliferation of diamond mining in the Northwest Territories near the border with Nunavut (also in northern Ontario), and the marketing of these diamonds as 'ethical' alternatives to diamonds from Sierra Leone, Angola, the Democratic Republic of Congo, and numerous other African countries. This is a form of nation-branding that privileges an abstract, universalized notion of Canadian nationhood, at the expense of more nuanced understandings of difference and struggle within this core-periphery relationship. The empirical core of this article consists of a series of focus groups with Inuks in Kugluktuk, Nunavut conducted during summer 2011, along with archival and interview research conducted in Yellowknife, Northwest Territories, concerning local reactions to the advent of diamond mining in the Canadian North. The article attempts to provide a missing geographic and historical context to the promotion of Canadian 'ethical' diamonds.

I begin with an exchange from a focus group conducted entirely with elders, and focus on the comments of a former trapper named George about changing community relationships with mining companies. Due to unavoidable translation constraints, quotes from the elders will be related through the interpreter's voice. $^{2}$

Interpreter: George says years and years ago, his experience was that people were mining without consent back then. They weren't even notified about mining way back then, through his experience, through his life, they really didn't let them know when they were on the land...

Moderator: But it's different now?

Interpreter: He said yes, he finds it a lot different today. George says that they're following better procedures now, the mining companies, you know the procedures they have to follow, the policies, and he said that for him in the past they would leave behind big barrels of you know, barrels and barrels of oil...

Later in the conversation...

Moderator: George, did you work for MMG? I just noticed your cap.

Interpreter: Oh, that's his gift, from MMG, at a community consultation. Oh, now he's joking that it took him forty years to get a hat!

George's characterization that relationships between mining companies and the community have improved is not uncommon, and in fact it would be incorrect and irresponsible to claim that the residents of Kugluktuk are opposed to diamond mining. Many of them in fact laud its potential economic and employment benefits. Such characterizations need to be understood, however, in the context of a palpable fatalism amongst respondents about changes in their community - that even if things were better before mining, the companies were there to stay, that life in the North had changed irrevocably, and that there are virtually no other economic opportunities available to the Inuit of Nunavut. George even alludes to this crucial historical dimension through a simple, if perhaps slyly cynical joke, in response to my question about

\footnotetext{
${ }^{1}$ Dr. Kolson Schlosser, Instructor, Department of Geography, Geology and Environment, Slippery Rock University, PA, USA. Email: Kolson.schlosser "at" sru.edu. Thank you to the American Philosophical Society, Simon Batterbury, two anonymous referees, all respondents, and Renee Krucas.

${ }^{2}$ I hired an interpreter for the focus group with elders, but this interpreter encountered a family emergency and was unavailable at the conclusion of the focus group to help with translation. The interpreter also turned out to be only semifluent in Innuinaqtun, although working very hard during the focus group to provide accurate interpretations.
} 
his ball cap. MMG refers to Minerals and Mining Group, a Chinese subsidiary currently expanding its prospecting efforts in the Canadian North. While George was generally enthusiastic about the increasing practice of 'community consultations,' he also quips that consideration by the industry amounting to the gift of a ball cap was a forty year long process.

And it is that forty year time span between barrels of oil left behind, and free hats for everybody, that provides the crucial historical and geographic context necessary to critique the possibility of consumption as ethical praxis. The point of this article is not necessarily to argue that Canadian diamonds are more or less 'ethical' than any other diamonds, but rather to critique 'ethical consumption' by situating it within that broader context. As with any community there exists a variety of opinions in Kugluktuk about mining, and George's enthusiasm was certainly matched by concerns over the environmental consequences, namely for water and caribou, and the socio-cultural impacts of mining. Such impacts are only part of the story, however. What the results of focus groups can highlight is that the very context in which positive or negative social impacts can be considered is more than forty years in the making. This context is a product of sociohistorical and economic processes that position both producers and consumers in their relative positions of cost and benefit, rather than a clear cut positive externality of consumer choice. Section three will detail how I have gone about building this argument, including further explication of what is meant by 'ethical consumption.' Before proceeding, however, a few notes on the geography of the Canadian diamond industry are necessary; see Figure 1 for general reference.

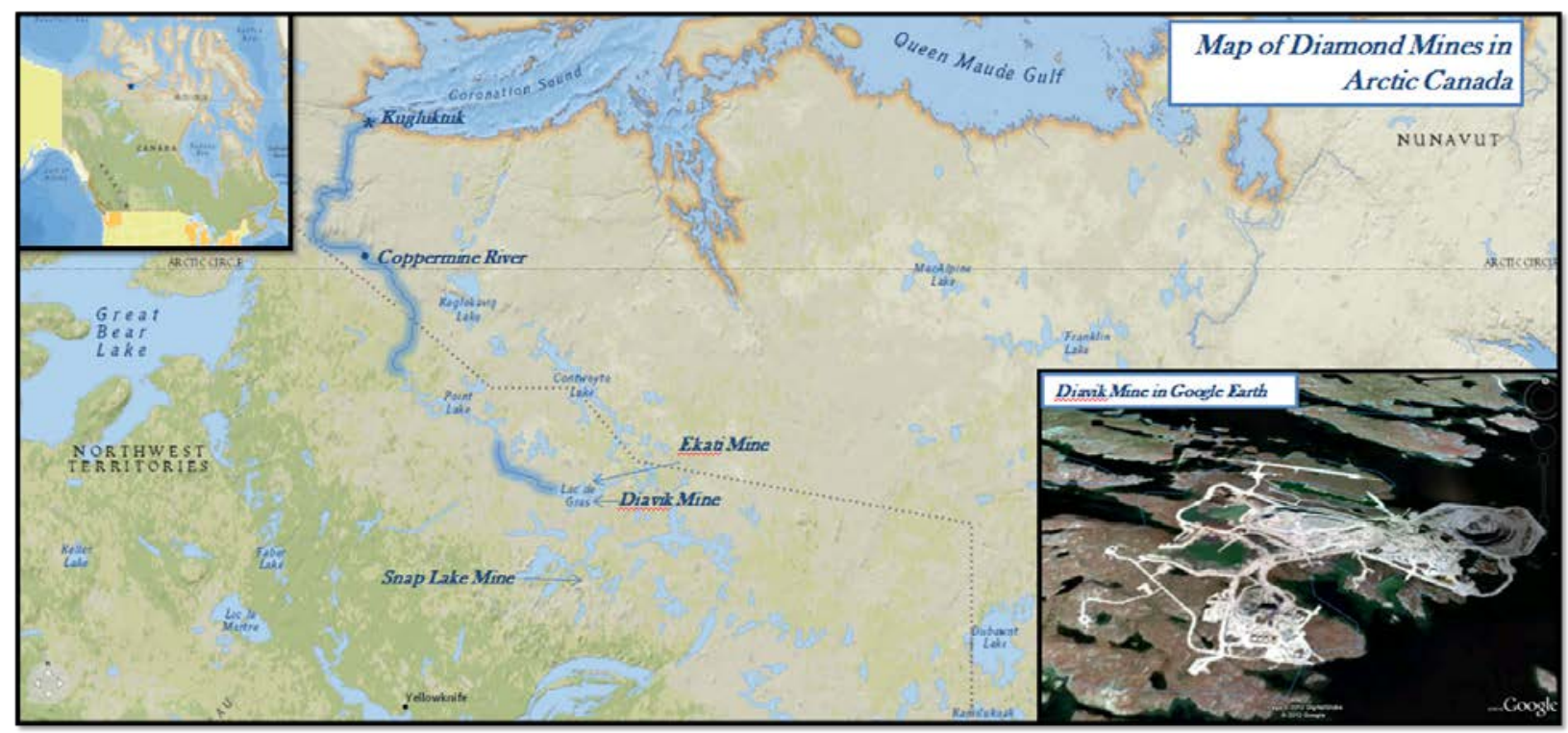

Figure 1: Kugluktuk, the diamond mines (underlined in red, centre of image) and the boundary between the North West Territories and Nunavut.

\section{Geographic context - diamonds in Canada}

Though mining in general has been commonplace in northern Canada since the early $20^{\text {th }}$ Century, diamonds were discovered as recently as 1991. Of Canada's four currently operating diamond mines, the three that exist in the Arctic are clustered in the eastern Northwest Territories (NWT) near the border with Nunavut. Of these three, the Ekati and Diavik Mines are within 50 kilometers of each other, and are both in the Lac de Gras region (Figure 1). Lac de Gras flows into the Coppermine River, which empties into the Coronation Gulf about 450 kilometers to the north. Kugluktuk itself, a village of approximately 1,300 people, rests at the mouth of the Coppermine River, in Nunavut. The third of the three NWT diamond mines is the Snap Lake Mine, located at Snap Lake just south of Ekati and Diavik. Diamonds from the Ekati, Diavik and Snap Lake mines are first shipped to Yellowknife where they are evaluated for royalty purposes, before being shipped elsewhere. Yellowknife is also where several government and private sector schemes to certify diamonds as Canadian take place, and these schemes are explained in more detail in a previous article (Schlosser 2013).

The Ekati Mine began production in 1999 and was previously owned by multinational mining conglomerate BHP Billiton, but recently sold a controlling stake to jewelry retailer Harry Winston Diamond 
Corporation for US\$ 500 million (DeMarco 2012). According to BHP Billiton (2011), the Ekati Mine accounts for three percent of global rough diamond production (by weight, not value) and employs 800 workers on site per year on average (not including off-site service contractors). The Diavik Mine began in 2003 and is owned jointly by Rio Tinto (also a multinational mining conglomerate) and Harry Winston Diamond Corporation. According to Rio Tinto (2009), Diavik employs about half as many people, but covers an area roughly nine square kilometers, making it significantly bigger than Ekati. The Snap Lake Mine opened in 2008 and is owned by DeBeers Canada, the Canadian subsidiary of the famous DeBeers cartel. According to DeBeers Canada (2011), Snap Lake is Canada's only underground mine (the others are large, open pit mines, though Diavik is in the process of becoming an underground mine), and employs an average of 635 workers per year. DeBeers Canada also owns the proposed Gacho Kue Mine at Kennady Lake in the NWT, the development of which is currently in limbo. ${ }^{3}$ The Ekati, Diavik and Snap Lake Mines all have an average lifespan of 20 years. Natural Resources Canada (2011a, 2011b) reports that approximately one quarter to one third of Diavik's and Ekati's workforce are composed of aboriginal labor. ${ }^{4}$

\section{Theory and Methods}

I use a similar form of analysis to Jackson's (2004) multi-sited, multi-scalar analyses of how meaning is made, received and often rejected in particular local circumstances (see also Jackson et al. 2009). I do not, however, share Jackson's normative assessment of ethical consumption. Rather, my approach it closer to Guthman's (2009), who characterizes ethical consumption as an example of commodity fetishism, and one that gains its influence by enabling the construction of the 'consuming self' as properly ethical (or not so ethical) (Goodman 2010; Schlosser 2013; Vander Kloet 2009). To understand this process, I draw on Hornborg's (2007) call to merge environmental history and political ecology perspectives. The results of the focus groups are therefore used to understand the situation of the respondents within the geographic and historical context that shapes them.

In that sense this article flows from examining the global to the regional (northern Canada) to the local (Kugluktuk) scale. In order to illustrate the relevance of context to the focus group results, it is useful to look at a selection of the young adult participants (in their late teens and early twenties) conducted in Kugluktuk, in which they were asked to respond to an advertisement for a brand of Canadian diamonds called Maple Leaf Diamonds. They were shown the following sales pitch from the Maple Leaf Diamonds (2010) website:

It was not long ago that the mention of Canada's Arctic evoked images of a hushed, frozen wasteland. Now, the Canadian North brings to mind Canadian diamonds, some of the world's most beautiful and scintillating treasures.

The participants' responses are quoted at length below:

Samantha: It's ... it's not a wasteland. Obviously they didn't try to come up here before when they put up that paragraph. I don't really like how they said that or worded it...I mean...

James: Maybe it was desolate before, but now...

Samantha: Life is not all about money and diamonds, and gold, if they came up here and actually experienced it, they wouldn't have said that...

James: They'd see that Inuks aren't only about diamonds and money, it's all about family, we're more about family, we tend to take care of each other. The only times we really care about money is when, say, none of us go hunting, and we need something to eat, then we'll worry about money, if we have nothing to eat, but then again if you're a skilled hunter and you go out and provide for your family.

Dustin: We depend on the work.

Samantha: The work. Nowadays all you need is the money...[laughs]

\footnotetext{
${ }^{3}$ Interestingly, the reasons for this depend on who one asks. DeBeers Canada officials told me this was due to regulatory red tape, though officials at the Mackenzie Valley Environmental Impact Review Board said that they were ready to proceed with a permit, but were waiting to hear from DeBeers Canada. There are prospecting efforts all over the NWT, Alberta and Saskatchewan, but the current state of the economy makes developing an economically viable diamond mine, which by definition produces a luxury good with elastic demand, very difficult. There was a diamond mine in Nunavut called the Jericho Mine (owned by a small Canadian company), from which the jewelry retailer Tiffany announced it would source all of its diamonds with great fanfare, but it shut down in 2008.

${ }^{4}$ Such statistics can often be tricky, as mining companies typically distinguish between aboriginal employment and aboriginal hiring practices, and focus on the latter. Thus I used Natural Resource Canada's figures.
} 
James: Back in the day, knowing nothing about money.

Samantha: yeah...

Dustin: Fishing for how many hours a day, sitting there... [group laughter]

James: God I stood at that one seal hole for a good four hours before I caught my seal, for four hours standing still, never moving once, only moving my arms, holding the hakapik... [looks at moderator]... the seal hook, god was I ever tired when I caught that seal, as soon as I caught it I pulled it out of the ice I sat right down on the ice and ... [sighs loudly]... took the biggest sigh I ever took in my life, and thank God I caught that seal!

Twenty-one year old James and nineteen year old Samantha were by far the most talkative participants in this group. One prominent theme that arises is that of how their community is misunderstood by outsiders who fail to experience it directly, as Samantha emphasizes early in the quote. Another is the change from a sort of casual indignation to a more somber tone, roughly at the point where Dustin suggests that "we depend on the work." At this point they begin to lament the loss of a previous cultural and economic life based on hunting and trapping. Their back-and-forth reminiscing - albeit of a life they are too young to remember themselves - recognizes, if implicitly, that Kugluktuk's historical transition from a subsistence economy, then to a cash economy based upon furs, to today's predominant wage economy brought with it a form of dependence on money. Cash is now an intermediary between themselves and their means of social reproduction. This is evident in Samantha's comment that "nowadays all you need is the money" and James's story of a very embodied experience catching his first seal.

This dialog illustrates that for the respondents, history and geography do not exist in a vacuum; hence my use of geographic and temporal scale to provide context to their remarks. Some have argued that focusing too much on scale potentially reifies hierarchies of power that such an analysis is meant to critique (Marston et al. 2005; Pain 2009). Ettlinger (2011) argues, however, that a scalar analysis does not necessarily reify a top-down organization of scale, and because power operates at multiple scales simultaneously (as demonstrated by Foucault 2003), it can help highlight the sources and the targets of power. It can, for example, help connect the long term change lamented by Samantha, James and Dustin in Kugluktuk with the signification of the ethical self through consumption (of the diamonds) in distant markets.

This issue can also be understood in terms of the nature of the ethics that are attached to commodity networks. The respondents' emphasis on an Inuit past, that they never experienced firsthand, reflects the emphasis Inuit communities often place on cultural memory through storytelling, due in part to anxieties over the loss of culture across generations. Stevenson (2006) argues that this emphasis is a matter of ethics in the sense of a Foucauldian technique of the self (Foucault 1995), rather than ethics in the sense of individual choices made within a moral code. Barnett et al. (2011) take a similar point of departure in their critique of ethical consumption, arguing that to assume it as a market response to better informed consumers is also based on a mistaken theory of ethics which presumes it as the selection of 'right' or 'wrong' options in the marketplace. This also presupposes individual consumers as agents of social change. Barnett et al. (2011) emphasize instead a theory of ethics which sees it imbued within the very structures of the market, capital, governance, culture, symbolic power, and so on, within which individuals find themselves, long before they can reify those structures via their choices. While I do not agree with their entire analysis, I do agree with their conception of ethics as a systemic, rather than individual, issue, and consequently I situate the ethicalization of Canadian diamonds within that larger scaffolding of political ecology and environmental history. I feel that doing so helps show the sources and targets of power, as the Canadian state and multinational capital incorporated the Canadian North into the dominant discourse of development. This also helps think more historically about, on one hand, mobilizations of consumer anxiety about the self and global hierarchy, and on the other hand about the provision of work and money which, according to the discourse of development, is supposed to enrich Inuit communities.

Focus groups are the primary method of this research because bringing community members together can help re-create the social dynamics through which anxieties about cultural degradation are produced and contested. While interviews were also used, they are limited in this regard (Litosseliti 2003). I conducted five focus groups - first a pilot group to uncover any problems, and then four separate groups for data analysis. The pilot group was held in Cambridge Bay, Nunavut, in the office of the Kitikmeot Heritage Society with full cooperation of their staff. It was useful to determine the (very wide) range of prior knowledge amongst participants about the current state of diamond mining in Arctic Canada (for instance, they were universally aware that the mines exist, but often unaware of how one would go about acquiring a job in them), and also to word questions as precisely as possible to accommodate respondents with a wide range of literacy. This was also helpful in that it highlighted the importance of assuring respondents that I am in no way affiliated with any mining company, as was sometimes the assumption.

The non-pilot groups ranged from two to eight participants, depending on how many participants were able to show up. One group consisted entirely of elders, and an interpreter was hired to help translate 
between Innuinaqtun and English. This group was graciously recruited by the director of the youth center in which the focus groups were held. Another group consisted entirely of young adults. Although flyers for the groups were posted around Kugluktuk, this group was assembled via word of mouth by some of the youth center employees. Another group consisted of a family of five, though they participated in two separate groups (two sisters in one group, and the parents and brother in another) due to their own time constraints. This group was recruited via an extemporaneous conversation initiated with one of the family members. A total of 26 respondents participated, and were paid \$40 for less than an hour of their time. ${ }^{5}$

Participants were initially asked about what they perceive as the benefits and risks of diamond mining, and how they see their communities changing (for better or worse), but the primary strategy was to keep the discussion open-ended, letting important themes emerge through intra-group communication. All groups were also shown advertisements for Canadian diamonds, which typically depict snowy, pristine landscapes, polar bears, snow geese, icebergs etc., or captions such as the Maple Leaf Diamonds passage cited above, in order to gauge their reaction (this strategy was also left open ended so as not to prompt any particular reaction; in fact reactions ranged from casual indignation to pride in the northernness of the product on display).

Kugluktuk was selected in the first place because of the Impact Benefit Agreement (IBA) it has with BHP Billiton, and the various other agreements it has with Rio Tinto and DeBeers Canada. IBAs are contracts negotiated directly between mining companies and aboriginal groups, and are one of the most controversial elements of the ongoing devolution of mining governance in northern Canada. ${ }^{6}$ The owners of the NWT's three active mines hold numerous IBAs with the T'licho, Yellowknives and Lutsel K'e Dene First Nations, along with the North Slave Métis Alliance in the NWT, the Hamlet of Kugluktuk and the Kitikmeot Inuit Alliance in western Nunavut. During previous research trips I conducted interviews with stakeholders involved in the diamond industry and the NWT, as well as archival research at the Prince of Wales Heritage Center in Yellowknife. That data has been directed to publications elsewhere, but does also buttress the data collected in Kugluktuk. The focus groups in Kugluktuk were conducted because it was necessary to fill in the gaps of an overall study of the northern Canadian diamond economy, and also because the Hamlet of Kugluktuk and the Kitikmeot Inuit Alliance have less regulatory jurisdiction over the mines because they are in a different territory (even if they are still downstream).

\section{Geographic context - diamonds in the world system}

Here I relate the history and movements of the global diamond industry that put issues of mining and development at Kugluktuk's doorstep. This helps provide context within which we can think about why Ben, an elder, stresses the employment benefits of mining despite concerns about risks to subsistence, again related through the interpreter:

Ben's answer to your question is that it's good for the community because it's employment, and as long as the animals aren't affected by the mines, like he doesn't have any problems with the mines because it's employment and it's beneficial for the family.

Or conversely, why Katrina, also an elder, emphasizes the long term cultural change facing her community (this came after several focus group participants agreed with Ben's assessment of risks and benefits of mining):

From Katrina's experience, she sees the lives here are changing because [of] money being brought in from the mines, and lifestyles are not as, you know, like they used to be, like they should be respected. ...Katrina says that there's drugs coming into town, and she's noticing that the RCMP are more involved with that, like we don't know where they're coming from, but that's one issue that's had an impact in our communities. ...Katrina says another really big social problem with the mines being here is that our young people are bringing in booze without permits, and it's having a really big impact on elders, especially for herself, it has a really big impact on her or her family.

\footnotetext{
${ }^{5}$ It is not believed that this cash influenced answers, as it was emphasized early and often that I had no relationship with mining companies; this a good example of why the pilot group was useful. Academic research, and the ensuing informed consent forms, was not at all unfamiliar to respondents, as this is a heavily researched area. Flyers were posted at points around town (mostly public bulletin boards) to advertise the focus groups, though they were largely ineffective. Participants were recruited either through word of mouth or via my gateway contacts who ran the youth center.

${ }^{6}$ The dollar amounts involved with IBAs are considered private information known only to community leaders, and thus are not available in this article.
} 
To be sure, local scale particularities in understanding social struggles are important (Marston et al. 2005), such as the nearly universal emphasis on family amongst respondents. I believe that a more persuasive argument is provided by Bridge (2008), who contends that most analyses of resource-related social struggles or uneven development should be situated within a Global Production Network (GPN) and not at the level of the nation state. Relating the background of the relationship between the global diamond industry and state power can help illuminate the matrices of power through which the risks, benefits and cultural change come to be in the first place (Ettlinger 2011). It is these to which Ben and Katrina offer their assessments. As a corollary to this, focusing on these 'matrices of power' at multiple geographic and temporal scales can help show the ethics of the diamond industry not in terms of the 'rational' decisions of ethicallyoriented consumers, but rather in more systemic terms concerning the expansion of, and struggles against, global capital as brokered by the state (Barnett et al. 2011).

Today's diamond industry, led by multinational capital and the retailing of diamonds to consumers as icons of social class, dates back to the early 1870s and Cecil Rhodes' creation of the DeBeers cartel in South Africa. Before that most diamonds were sourced from colonial India or Brazil, and were adorned primarily by European royalty (Berman 1971). Rhodes's efforts were bankrolled by British elites who worried that the South African diamond rush of the 1860s would lead to a worldwide glut and collapse in the value of their accumulated gems. In return, Rhodes infamously created the DeBeers cartel, a loose syndicate of organizations designed to control the price of diamonds primarily by limiting supply (Roberts 2003).

As Huber (2011) points out, violence is not always the outcome of scarcity or even abundance, but is often an instrument used to create scarcity in order to regulate the marketplace. The value of diamonds did not arise out of a natural 'scarcity'. Rather, scarcity was constructed by a coalition of state and capital that controlled market conditions. Control of the commodity chain, however, was predicated on territorial control of present day South Africa, Botswana, Namibia and Angola. To do this, in conjunction with the British Colonial Government, Rhodes used his fortune to raise standing armies, which were used not only used in the Boer War for the purposes of razing entire villages and farmsteads and the internment of Boer settlers (Meredith 2007), but also the subjugation of native populations, something about which Rhodes was very explicit (Smillie 2010).

African conflict diamonds, or 'blood diamonds,' typically refer to illicitly traded gemstones used to fund civil war by non-state entities. But given that the modern diamond industry itself is built upon a fusion of capital and the state in order to control territory through disciplinary power, all diamonds can potentially be thought of as conflict diamonds. The alienated labor value which results from this power is one of the internal contradictions of capitalism that is circumvented through various means, including territorial expansion. For instance, Moore (2007) points out that the European silver industry circumvented its own environmental and labor limits in the sixteenth century by relocating to South America. Similarly, the DeBeers cartel purchased all loose diamonds on international markets and stockpiled them, dictated prices to its purchasers in London (which it owned), and used its market power to punish dissenters (Spar 2006). After being taken over by the Oppenheimer family in 1925, DeBeers produced scarcity in order to inflate value and regulate global markets.

DeBeers became involved in Sierre Leone by the 1950s. At that time the diamonds produced there were outside of DeBeers' control and thus a threat to their ability to produce scarcity. ${ }^{7}$ DeBeers' expansion into West Africa to purchase loose diamonds can also be seen as a move to discipline unruly labor and dispossess the value of the work done by artisanal miners. DeBeers has since divested itself from Sierra Leone, at least formally, but only after the decline of its monopoly and after the country's notorious diamondrelated civil war of the 1990s. Even as recently as 1999, DeBeers CEO Nicky Oppenheimer stated the importance of organized capital in resource exploitation, rather than local people:

The key element is not the resource itself, but how it is exploited. An orderly mining regime, operating within a transparent and predictable legislative and fiscal framework, can be a major source of prosperity for governments and people. Without it...mineral wealth will be a magnet for the greedy and corrupt to line their own pockets at the expense of the people. (Nicky Oppenheimer, quoted in Smillie 2010: 156)

\footnotetext{
${ }^{7}$ DeBeers set up its own 'task force' to bring Sierra Leone's loose diamond production under its own aegis, on the pretense that otherwise those diamond would be smuggled into the Soviet Union and used for industrial purposes at the beginning of the Cold War. According to Kempton and Levine (1995), Roberts (2003) and Smillie (2010), this claim is probably fallacious given that the Soviet Union had stockpiles of diamonds large enough that Sierra Leone's were inconsequential. It was likely the Soviet Union's ability to control prices that was the biggest threat to DeBeers, and also a factor in the unraveling of its monopoly.
} 
Oppenheimer's argument turns on narrow conceptions of violence and sovereignty, and takes capital accumulation for granted. In contrast, Paul Richards' (2001) contrasting account of Sierra Leone's civil war is far more convincing. He suggests that Sierra Leonean rebels in the 1990s originally reacted to the appropriation of mineral wealth from diamond diggers by outside capital. Only later did their campaign lose this political coherency. Similarly, Akiwumi (2012: 582) argues that "the overarching driver of mining area conflicts [in Sierra Leone] is the asymmetry in power relations between global core-state corporations and weak peripheral nation-states." Richards' and Akiwumi's accounts are powerful because they situate diamond-related conflicts within the broader structures and movements of multinational capital, in this case the diamond industry.

This may appear far-flung from the particularities of lived experience in Kugluktuk, or elsewhere in the Canadian Arctic. I contend, however, that it does matter. First, the competing concerns about employment and cultural change articulated by Ben and Katrina are a consequence of resource colonialism driven by the state and by capital. In northern Canada, resource extraction had long been justified by the same betterment discourse of which Oppenheimer speaks (Bednasek and Godlewska 2009). At the crux of Oppenheimer's characterization is the assumption that 'the people' do not possess sovereign ownership of their labor, and exist as beneficiaries of the order that is imposed upon them to create value (rather than being the source of that value in the first place). Secondly, this assumption is crucial to the construction of the 'value' of Canadian diamonds, as Canadian diamonds are said to be ethical compared to those from Sierra Leone. From the perspective that Oppenheimer advocates, they are ethical because they do not emanate from the extreme disorder of a 'diamond war.' If seen from Richards' (2001) and Akiwumi's (2012) point of view, however, it is an imposed order - the disciplining of unruly labor - that engenders conflict in its various forms, turning the notion of ethical consumption on its head. Thirdly, this issue of the sovereignty of labor and whether ordered dispossession is any less "greedy and corrupt" than disordered dispossession in Sierra Leone shines a certain light on the diamond industry's expansion into Canada in the first place. Richards' (2001) and Akiwumi's (2012) analyses suggest that the West African 'diamond wars' reflect the very contradictions of capitalism that are circumvented through territorial expansion (the fact that there are profitable sources of diamonds there explains only where they went, not that they went somewhere). ${ }^{8}$

The marketing of Canadian diamonds as ethical alternatives is also an extension of techniques employed by the industry to circumvent barriers to accumulation after WWII - primarily the creation of new markets. Despite the gradual decline of its monopoly over the latter half of the $20^{\text {th }}$ century - a monopoly designed to keep prices high - the actual retail price of gemstone diamonds increased 1,800 percent between 1948 and 1990 (Kempton and Levine 1995). ${ }^{9}$ This was due in large part to DeBeers' new use of advertising to inflate prices through demand, rather than through supply. During WWII, in order to access American markets, DeBeers launched a series of advertisements suggesting to women that it was more 'patriotic' to keep their diamond jewelry than to donate it to the war effort, because the company wanted to prevent the creation of a second-hand diamond market. This led to the infamous slogan, 'a diamond is forever,' ostensibly to link diamonds to life-long love, but also to personal economic security and, again, to cheapen the idea of secondhand diamonds in order to regulate supply. In post-war Japan, however, they promoted diamond ownership as a symbol of modernity more than love and devotion, and this had a similar impact on sales (Roberts 2003).

Though its history still influences the structure of the industry today (Spar 2006), DeBeers lost its dominance in terms of market share by the 1970s for a variety of reasons, from the Soviet Union's stockpiles of diamonds, to increased production in Australia, to international pressure on the Apartheid regime in South Africa, and also the improved geological knowledge of how to prospect for diamonds. The latter allowed many more competitors, including BHP Billiton, Rio Tinto and numerous junior companies, to gain a foothold in the industry. Facing decline in market share, DeBeers liquidated much of its stockpiles and began producer-of-choice marketing by adding its 'forevermark' insignia to what was, by the 1990s, a proliferating number of diamond brand names.

These changes in marketing mirror changing understandings of the consumer more broadly, and speak to the issue of ethical consumption. Early to mid- $20^{\text {th }}$ century literature on consumption posited either a consumer that was entirely driven by class consciousness or, later, consumers that were overwhelmed and anxious about a bewildering array of choices (Trentmann 2006). One industry survey even revealed buying diamonds as "one of the most anxiety-ridden experiences an ordinary shopper can have" (Smillie 2010: 51). The concept of ethical consumption reflects neoliberal economic trends since the 1980s, with the emphasis on signaling to the consumer an alleged sense of choice. Thinking about the mythos of the ethical, discerning consumer within the broader context of global commodity networks for diamonds, and situating it relative to, for example, Katrina's concerns about social change in Kugluktuk, helps qualify the theory that consumers are agents (rather than products) of social change. By situating local realities within broader commodity

\footnotetext{
${ }^{8}$ Even current attempts to police illicitly traded diamonds through the Kimberley Process Certification Scheme, meritorious though such attempts are, can be seen as disciplining the market by creating scarcity.

${ }^{9}$ Prices continued to increase steadily up to 2008 (Spar 2006).
} 
networks, I do not mean that Inuit culture has been usurped by global capital or that Inuit society has been hopelessly commoditized, but rather that it is necessary to investigate how the spread of multinational capital, brokered by the state, manifests itself at the local scale, at least in Kugluktuk. My goals are simply to examine how focus group participants themselves react to the proliferation of diamond mining in the Canadian North. For that reason I turn now to the diamond industry in Canada.

\section{Historical context - the Canadian North}

To be sure, a vibrant system of trade existed in the North before Europeans made contact with aboriginal populations, particularly through the Hudson Bay Company (Stern 2010). The long history of the incorporation of these Northern systems into the Canadian polity and into global systems of exchange are intrinsic to the process of capital accumulation. This history is also fraught with material and discursive orderings, which can shape life in Kugluktuk just as they are contested by its residents. For instance, sisters Katie and Kristin, 23 and 20 respectively, were shown the same sales pitch for Maple Leaf Diamonds discussed above:

Kristin: It's still... Some parts of Canada are still frozen. You were saying that the Maple Leaf diamonds represent um, Canada, as one, but here there's two parts. Most of Canada is not, most of Canada has no ice and snow, so they should um... [looks up at moderator ${ }^{10}$ ] ...rephrase the whole thing.

Moderator: Ok. Ok.

Katie: They should rephrase, they call this a wasteland? Frozen wasteland? That it was untouched for several hundred years, but by Inuit. They only started coming 1900s?

Kristin: Not even.

Their reaction challenges the notion of a singular (even if allegedly multicultural) Canada, the discursive construction of their land as something to be exploited for the betterment of the people who live on it (as Nicky Oppenheimer would suggest, above), and the entire legitimacy of southerners making any sort of knowledge claim about territory with which they have little direct experience.

The search for mineral resources long precedes the 1900s, and its history is complex. In short, as the Canadian state confederated in the $19^{\text {th }}$ century, it established numerous treaties with northern aboriginal groups, which preserved aboriginal title to the land itself, but without subsurface rights or autonomous governance. This created a complex legal geography that has been politically contentious ever since, with the state and capital institutions negotiating for the extinguishment of aboriginal title to land in exchange for them receiving devolved forms of governance over education, hunting and fishing rights, etc. This was formalized in the late 1950s under the Diefenbaker administration, which claimed 'northern development' was central to Canada and its arrival as a world power. The developmentalist logic of those times is implicit in Maple Leaf Diamonds' advertisement, and appears to be the target of Katie's and Kristin's disdain. Such colonial narratives also have material consequences, as elaborated in Cameron's account of the role of copper exploration in how local histories of Kugluktuk are written (2011). Moreover, numerous high profile development projects had important impacts on aboriginal life, including (though not limited to) uranium mining (Keeling and Sandlos 2009), hydropower development (Desbiens 2004), and the construction of the Distant Early Warning System (Lackenbauer and Farish 2007).

By the 1970s, the resource extraction industry placed significant pressure on government to facilitate the land claims process. Settling a land claim in this context basically meant the extinguishment of aboriginal title to the land, which the industry argues is necessary to create a stable investment environments lauded by Oppenheimer. For example, in 1986 the NWT Chamber of Mines, a northern mining industry trade association, wrote to the minister of the Federal Department of Indian Affairs and Northern Development urging them to expedite land claims settlement, with the following as part of their justification (NWT Chamber of Mines 1986a, emphasis added):

The North needs more investment which will result in more jobs for Northerners and, ultimately, foster the growth of a strong northern economy and a proud, self-determining northern society... Industry's hesitation towards further investment reflects two principal concerns: doubts over government's commitment towards strengthening the North's mining sector, and increasing alarm over threats to both mineral tenure and access to subsurface rights.

\footnotetext{
${ }^{10}$ The moderator is the present author throughout this article.
} 
A couple of things should be pointed out here. First, the Chamber of Mines - which can be thought of as a proxy for capital interests, more or less - argues for government involvement to resolve what they see as the most important threat to investment, that their access to capital accumulation might be interrupted. Second, their justification for this access is that northern populations, which in this context largely means aboriginal people, are now dependent, but would become 'self-determining' if they were dispossessed of their mineral resources under the conditions of 'order' that Oppenheimer suggested. The fact that the Chamber of Mines' understanding of 'self-determination' is flawed when placed in historical context will be dealt with in the next section. Their view of the relationship between themselves, the state and aboriginal populations is described clearly in a history of aboriginal land claims they authored in the same year. In this document they refer to aboriginal title as a "privilege" (NWT Chamber of Mines 1986b: 2) and that the purpose of the previous treaties was to enable the Federal government to undertake "the clearing of aboriginal title to facilitate various development projects and the expansion and consolidation of Canada through settlement" (NWT Chamber of Mines 1986b: 3). Thus land claims negotiations can be seen, at least in this context, as the transfer of mineral rights from aboriginal people to capital interests brokered by the state, with aboriginal sovereignty portrayed as the barrier to overcome for the sake of aboriginals themselves.

Land claims are still a contentious issue in the NWT, but Nunavut's land claim was settled seven years later in 1993, creating Nunavut as a separate territory. This does not mean that Nunavut gains royalties from mining - because it is a territory and not a Province, it cannot by definition collect royalties on most of its land, though it does receive transfer payments from the capital, Ottawa. Nunavut also only owns about 20 percent of its land area and 2 percent of its subsurface rights. As mentioned at the outset, the Hamlet of Kugluktuk and the Kitikmeot Inuit Association (KIA) - a governance institution responsible roughly for the western one-third of Nunavut - have been able to negotiate Impact Benefit Agreements with most of the mining companies, which provides cash payments to communities, scholarships and job training programs. These are not regulatory in nature however, and can be a source of dispute within communities as to who should negotiate them; Hamlet officials often argue that they have too little say in IBA negotiation compared to the KIA. ${ }^{11}$ Simpson (2003) maintains that many elders in Inuit communities feel that the benefits spelled out in IBAs are insufficient. Many of the focus groups respondents in my research were enthusiastic, if perhaps cautiously so, about IBA benefits. But interviews with officials who have directly negotiated IBAs with mining companies reveal that they were originally negotiated under extremely unequal conditions of power and knowledge (though in some cases they feel that this reality is slowly changing).

The discovery of diamonds in Canada in 1991 by two geologists has since been mythologized in industry lore. Stories of two dashing explorers outwitting the DeBeers empire (DeBeers had been exploring for diamonds in Canada since the 1970s) and bringing economic salvation to northern aboriginals parallel the imagined geography we saw with the Maple Leaf Diamonds advertisement. This also brings me to the advertising campaign I mentioned earlier. Corporate actors in the upstream portions of the commodity chain don't often make direct reference to 'conflict diamonds,' though they do rely on snowy white landscapes, polar bears, icebergs, etc, in a way which suggests a racial semiotics is at play when contrasting them with popularized images of a 'dark' African continent. Downstream actors, specifically jewelry manufacturers and retailers, do often make explicit reference to conflict diamonds, and rely on a certification program run by the Government of the Northwest Territories; on donations of a percentage of proceeds to development related charities; or on the Kimberley Process Certification Scheme in order to claim their product as 'fair trade' alternatives. Such advertisements are effective because they position the consumer against dual spatial imaginaries, one within Canada, and the other in contrast to Africa (Schlosser 2013). The 'ethics' in ethical consumption here can be seen as a 'technique of the self' for the consumer, rather than as a guide for their purchasing options. Following Bourdieu (1984), this can only take place within a field of power and meaning that is pre-figured by historically accumulated symbolic capital ('habitus').

The dominant Canadian national narrative of a multi-cultural society is part of this symbolic capital. The critical response to this narrative is that it obscures very real inequalities, and in fact helps to preserve racial hierarchy by imagining a national space in which citizenship rights and economic salvation are gifts provided by the core population to aboriginal, immigrant and francophone groups. Focus group participants were shown the following sales pitch from the website of Eskimo Diamonds (Eskimo Diamonds 2009):

The Canadian Eskimo culture is characterized by a close relationship with the natural world. Life depends on an intimate knowledge and understanding of nature, and as a result the Eskimos recognize fewer barriers between themselves and animals, plants, rivers and mountain [sic] around them...The same respect and ethics are used in mining every Eskimo Diamond.

\footnotetext{
${ }^{11}$ IBAs themselves are private documents held in the municipal offices of communities and are not available to researchers as a general rule. See http://www.atns.net.au/agreement.asp?SubcategoryID=166\&EntityID=2303
} 
Thus, what is unique to the flourishing diamond industry in Canada is the sense of moral responsibility with which all operations are studied, planned and carried out.

They critiqued the narrative. The use of the term Eskimo is something that stood out right away to most participants. Smitty, in his 50s and relatively well educated, was the first to joke about it, somewhat playfully. He acknowledges the relationship between Canadian diamonds and conflict diamonds:

Smitty: Well you can tell right away that your study is probably more American, because most of us here we prefer to be called Inuit to Eskimo.

[Group Laughter]

Smitty: I think they use the term Eskimo because most of the world first knew us as Eskimo.

Moderator: Any other reactions to this?

Smitty: Well, this branding of diamonds, I guess you know it's a benefit to a Canadian diamond mining industry, because like I said there's those blood diamonds involved in Africa. The money there can be used to commit atrocities ... So it's a good thing I guess there, you know...

Samantha, who we heard from earlier, was perhaps the most genuinely offended, though even she jokes about the prospect of a lawsuit. This was after her friend James interrupted her, and then switched course to follow her lead:

Samantha: First...

James: I'd say, if I wasn't from Canada, that would definitely get me buying a diamond.

Samantha: The Inuit don't like to being called Eskimo, that's...

Moderator: Derogatory?

James: Yeah, it's like calling black people the N word...

Samantha: We don't like to be called Eskimo, we prefer Inuit people, or Inuk.

Moderator: That's what I thought...

Samantha: It's offensive.

Moderator: I understand...

Samantha: We should sue them [laughter]. You're offending me [as everybody laughs]!

Thus, dominant cultural narratives are, unsurprisingly, met with counter-narratives, even if playful ones in this particular case. The use of the 'environmentally ethical aboriginal' in the Eskimo Diamonds advertisement is characteristic of how the North of the nation is often constructed within the dominant narrative - as a source of purity and timeless in the face of urban change (Panelli et al. 2009), and as a source of national identity (and mineral resources). Lauding the ecological virtues of so-called 'eskimos' as a key component of the Canadian cultural mosaic also invokes a false normative equivalence (as described by Baldwin 2009), as though consumers of Eskimo Diamonds in the South are showing solidarity or somehow identifying with the Inuit. Samantha problematizes this false equivalence, as she and her friends James and Dustin continued with their discussion of the Maple Leaf Diamonds advertisement cited above:

Samantha: It's just not that bad of a wasteland, it may look like a frozen desert, but it's not that bad.

James: It's very beautiful when you look at it in a different point of view... you just gotta spend enough time out there on the land to see it. You can't just spend 15 minutes out there and say oh, it's a wasteland. ..

Samantha: I like that they put a maple leaf here though. That's Canadian [slightly sarcastic]

Moderator: Yeah they laser serial numbers on the diamonds, and other things like maple leaves, sometimes polar bears...

Samantha: Yeah those are rare, I heard those are rare! I wouldn't mind one of those [gestures to boyfriend Dustin]

Dustin: I disagree with you! [laughter all around; this was in response to moderator's early suggestion that they should feel free to disagree with each other]

After a period of general horseplay...

Samantha: And it's going to be a maple leaf, that's better than an Eskimo [sarcasm] 
It is clear in the advertisements that a colonialist narrative prevails. This narrative suggests that the Canadian North was a wasteland until value was added to it through exploration and capital investment, and this inclusion of the 'true north' into the so-called Canadian multi-cultural mosaic is central to Canadian identity. But we always see counter-narratives expressed by these focus group participants. There was Kristin's idea of separate Canadas, to Samantha's joke (to be understood by her peers) that a maple leaf, as a representation of Canada, could be superior to an Eskimo, a representation made of her people, although an incorrect one. These are not meaningless narratives, but rather, as Cameron (2011) persuasively argues, they matter materially in terms of the lived experiences of the Inuit in Kugluktuk. I will elucidate how, and why, in the next section.

\section{Historical political ecology}

I have attempted to contextualize focus group conversations by interpreting them within the histories of economic, cultural and ecological change in the central Canadian Arctic (a 'historical political ecology'). The cultural change brought by economic globalization is constantly contested, re-interpreted, and re-worked in local contexts. For example time-discipline ${ }^{12}$ is not an inevitable consequence of modernity in many Inuit villages (as it is in wage-based societies in capitalist economies) (Stern 2003). The Inuit concept of Inuit Qaujimajatuquangit (IQ), which roughly translates as "the things that Inuit have known for a long time" (Stern 2010: 33), has been incorporated into the governance systems of the Government of Nunavut (Wenzel 2004), as a way of articulating cultural continuity over time in the face of change. Dowsley (2010) points out that many Inuit villages are still not driven by western economic ideals; they set low quotas for polar bear hunting (often for tourists) below what would be most economically profitable, in order to preserve them as a collective, common-pool resource. ${ }^{13}$

The hybrid systems operating in the North should be investigated and placed within historical and geographic context, because this shows how power is organized and operates at multiple scales. Those IQ principles, for instance, have been illustrated in a book about their use in caribou herd management called Thunder on the tundra (Thorpe et al. 2001). ${ }^{14}$ Stern (2010: 33) refers to IQ as an "elite movement," in the sense that it is a construct of Inuit political leaders; ${ }^{15}$ some focus group respondents had only a vague idea of what $I Q$ is, while some of the younger respondents had never heard of it.

There is widespread concern, especially amongst elders, about social change and cultural degradation in their communities. Inuit elders stress the importance of cultural memory, including the importance of learning through experience, to youth as fears of cultural loss abound (Stevenson 2006). This is not specific to the Inuit, and can be observed amongst Dene elders in the Northwest Territories (Andrews 2004; Crate 2006). Personal experience and direct knowledge from the younger participants (Katie, Kristin, James and Samantha) also illustrate concern, particularly in Katrina's remarks quoted above. This is important in assessing claims for ethical Canadian diamond sourcing.

Smitty suggests intergenerational problems in this exchange (upon being asked about the risks involved with mining):

Smitty: Well people have the money to spend so, you know, like, we have a high percentage of our population that, you know, get into substances.

Moderator: Would you connect that to the mines? I mean has substance abuse become more prevalent since mining began?

Smitty: Well of course, I mean you see Kugluktuk there, I have family that say yeah there's a big problem there because people have money they don't know what to do with, how to spend it. It's a downside of not knowing how to manage money.

Moderator: Anybody else? ... I mean, does life around here change rapidly?

Smitty: Oh yeah. Like our whole culture there, most of the people nowadays, the kids there, the young people there, they can't speak our tongue, our native tongue, so it's a loss of culture.

Smitty highlights substance abuse and the loss of language. These were frequent concerns in the focus groups, though it is important to bear in mind that other issues such as suicide and spousal abuse are less likely to be discussed in a focus group format (or even interviews, given my non-resident status). Based upon

\footnotetext{
${ }^{12}$ The rules, conventions, customs, and expectations governing the measurement of time. See Thompson (1967).

${ }^{13}$ Neither Stern's (2003) nor Dowsley's (2010) examples are specific to Kugluktuk. In fact polar bears are rarely spotted in Kugluktuk.

${ }^{14}$ It is noteworthy that this book was partially funded by BHP Billiton.

${ }^{15}$ Searles (2006) points out that cultural preservation can often be a tool of political control, even in Inuit societies.
} 
her discussions with women in Kugluktuk, Simpson (2003) suggests that the transition to wage economies brought by mineral development changed male roles in the family from being providers - through hunting and trapping - to relying on cash for outside commodities. She also suggests that the resulting materialism and commoditization has led to a questioning of Inuit values, increasing youth suicide (a rampant problem in Kugluktuk) and, her respondents said, men becoming more controlling in the household. The transition from a fur-based cash economy to a wage-labor economy was ushered in by a coalition of state and capital - the process that the NWT Chamber of Mines felt would create 'self-determining' northern societies. Tester and McNicoll (2004) add that the myriad possible explanations for the high rates of Inuit suicide underestimate the history of colonial governance as a contributing factor.

The history of colonial governance brings us back to that forty year time span that it took George, quoted at the outset of this article, to get his MMG hat at a community consultation. After his joke about the hat, George continued:

Interpreter: George said from his younger days, he didn't work as a miner ...but he made his living as a trapper. But because he cares he attends a lot of these mining meetings, he wants to make sure our land is ok, he's here to support whatever meetings there are about mining.

George's statement is that now that there's mining on the land, he's noticed that there's less foxes, that they used to trap... George's statement was that because there's mining, if the mines stopped right now, if for some reason they all of a sudden closed, how would it have a big impact on the trappers? That's his statement; there would be no money for the trappers if the mines closed all of a sudden.

Right now George is saying that he's very pleased with the mining companies because they're helping our community, for example they're helping the hamlet with needing money. ${ }^{16}$

George indicates here the economic transitions throughout his lifetime and the material realities which inform his cautious support of the mining economy (including but not limited to diamonds). His point (after consultation with the interpreter) was that hunting and trapping had changed. Locals now require many more material objects, such as snowmobiles, rifles, traps and other hunting equipment, which of course requires cash, which requires wage labor. Stern (2010) and Dowsley (2010), among others, both point out that these wages are necessary in the light of long term structural changes owing to "the centralization of human settlements, market forces, and formalized wildlife management" (Dowsley 2010: 43) - factors introduced by the nexus of state and capital. Tester (2006) makes an excellent point with regard to government-provided housing built in the 1950s to replace the low grade housing provided by mining companies in the 1940s. He argues that accusations that such housing will create dependency on the state are misplaced because the issue is whether people are dependent on the market or the government. One wildlife manager in Kugluktuk told me that in his younger days (he was in his 50s, well younger than George) he could work roughly seven months out of the year and make upwards of \$50,000; this form of 'self-sufficiency' is no longer possible. These observations challenge the NWT Chamber of Mines' assumption that self-sufficiency is a consequence of wage labor.

Dependency on mining wages also informed the responses by many of the younger participants, who had concerns about getting access to employment in the mines:

Katie: I wouldn't mind to go to one of the mines for work. I wouldn't mind to drive one of those heavy equipment operators.

Kristin: They're hiring at Hope Bay. ${ }^{17}$

Katie: I think I'm going to do some training this year .... I think I'm going to get my driver's license.

Many participants commented on the need for proper skills, not to mention the high school diploma that is required by most mining companies, to work in the mines. Maggie, for instance, had little idea of how to go about getting such a job, to which Lewis suggests getting a resumé:

\footnotetext{
${ }^{16}$ This refers to the Impact Benefit Agreement the hamlet of Kugluktuk has with BHP Billiton.

${ }^{17}$ Hope Bay is a gold mine currently under construction.
} 
Maggie: The thing about diamonds, how do we get into the diamond mines? I know they have work out there for them. Is it just for anybody that wants to apply, you can just apply?

Moderator: You mean to work in the mines? I'm not sure how it works.

Lewis: You get your resumé done.

The mines do provide jobs, though the accessibility and sustainability of employment is questionable. The value that George, Katie, Kristin, Maggie and Lewis put on these jobs is entirely understandable, and their qualified support for mining is far from unwarranted. The point here is not to say whether mining is good or bad or whether Canadian diamonds are 'truly' ethical or not, but rather to consider the very question of commodity-based ethics within the context that George himself provides. To think of a given commodity as either ethical or unethical based upon the conditions of its production risks seeing it in a context that is too narrow. In this case, the claim about 'ethical' Canadian diamonds ignores the extension of the commodity relationship to northern Canada in the first place. The extension of that commodity relationship (in worldsystems language, the peripheral Canadian North as supplier of raw materials to the southern Core) reflects the need of multinational capital to circumvent its own environmental and labor contradictions which limit its ability to accumulate more capital. Ethical consumption should perhaps be seen in terms of power throughout commodity networks, rather than in terms of whether given commodities meet arbitrary criteria to be considered ethical (as in 'Canadian ethical diamonds').

Many focus group participants also cited environmental concerns. Lewis, in fact, followed up Smitty's discussion of the socioeconomic impacts:

Lewis: Animals too.

Moderator: Animals? What's the impact there?

Smitty: Scare the animals away there. Effect the migration routes of the caribou.

Smitty: Because most Inuit up here you know, that's their, you know, their native food, like the caribou you know.

Lewis is referring to the fact that the diamond mines exist within the traditional migration routes of the Bathurst caribou herd, and they could prevent the herd from replenishing its numbers during the summer. While support for mining amongst the Inuit is nearly always contingent on environmental considerations, there is little scientific consensus on the impact of mining on caribou, with industry-funded studies often contradicting independent or government-funded studies. So too is the case with the other main environmental concern, which is that ammonia from explosives used in diamond mining could pollute the Coppermine River. The Environmental Monitoring Advisory Board (EMAB), an independent monitoring agency which the Diavik Mine is required by law to fund, reported a shortage of Daphnia in the Coppermine River. ${ }^{18}$ Diavik then substantially slashed EMAB's budget, officially for unrelated reasons. All mining companies fund corresponding monitoring agencies, though the relationship between Diavik and EMAB is much more contentious than is the case with the other mines (based upon interviews conducted for this research), and Diavik itself is viewed much less favorably in Kugluktuk than is BHP Billiton and DeBeers Canada. Based upon its land claims agreement in 1993, Nunavut actually has considerable authority in environmental regulation and protection within its own borders, but recall that the diamond mines themselves are in the NWT, not Nunavut. Given the transboundary movement of water and caribou it has little authority over them. Those monitoring laws, in fact, are mandated by the Government of the Northwest Territories, while land and water regulations and permits are handled by a series of co-management boards established via land claims agreements in the NWT.

\section{Conclusion}

The environmental issues surrounding the mining of Canadian diamonds are more complex than this, and just one of the potential areas for future research. While environmental quality was important to most participants, many of them (such as George and Ben) felt positively that the mining companies would keep up effective monitoring procedures (perhaps less the case with Diavik), which is mostly due to the proliferation of 'community consultations' as a standard practice by mining companies (as George alluded to above; in fact many participants initially thought the focus groups were organized by a mining company). Even the generally pro-development McPherson (2003: xviii) refers to these consultations as a "sham" - an assessment that is difficult to disagree with given my own experiences attending them. Consultations are one

\footnotetext{
${ }^{18}$ Daphnia are small planktonic crustaceans, sometimes called water fleas, which serve as detritus feeders and reduce algae.
} 
of many examples of how multinational capital morphs and fuses itself with local contexts, and thus are another important topic for future study.

This research has helped to put the idea of consumption as ethical praxis in much needed historical and geographic context. To ask whether a given commodity is ethical or not, based upon the risks and benefits born at the point of production, is the wrong question. I argue that it is more important to see 'ethical consumption' as a mobilization of ethics, understood as a technique of the self, and as a mode of power (Guthman 2009). This rendering of ethical consumption is more visible when seen in the context of the production of those risks and benefits over the long term. In this article, I have drawn a thread through the diamond industry's need to circumvent its own labor and environmental barriers to accumulation, and into its construction of capital accumulation as an imposed 'order' that creates wealth through dispossession. This was principally in the form of territorial expansion and the regulation of markets, first through constructing scarcity and then, in the face of a loss of monopolistic control, through constructing demand. This comparatively high degree of 'order' forms the basis of how Canadian diamonds are said to be 'ethical,' though it is also the very process that creates new needs (wages) to be satisfied by mining in the first place. Constructing Canadian diamonds as ethical alternatives privileges a colonial discourse in which dependency on markets and wages figures as 'self-sufficiency', while ignoring the very dispossession that destabilized self-sufficiency in the first place. The focus groups conducted in Kugluktuk help demonstrate this.

\section{References}

Akiwumi, F. 2012. Global incorporation and local conflict: Sierra Leonean mining regions. Antipode 44(3): 581-600.

Andrews, T. 2004. "The land is like a book": cultural landscape management in the Northwest Territories, Canada. In I. Krupnik, R. Mason and T. Horton (eds.) Northern ethnographic landscapes: perspectives from circumpolar nations. Washington, DC: Smithsonian Institution. Pp301-322.

Baldwin, A. 2009. Ethnoscaping Canada's boreal forest: liberal whiteness and its disaffiliation from colonial space. The Canadian Geographer 53(4): 427-443.

Barnett, C., P. Cloke, N. Clarke and A. Malpass. 2011. Globalizing responsibility: the political rationalities of ethical consumption. Oxford: Wiley-Blackwell.

Bednasek, C. and A. Godlewska. 2009. The influence of betterment discourses on Canadian Aboriginal peoples in the late nineteenth and early twentieth centuries. The Canadian Geographer 53(4): 444461.

Berman, M. 1971. The location of the diamond-cutting industry. Annals of the Association of American Geographers. 61(2): 316-328.

BHP Billiton. 2011. Celebrating the discovery: Ekati Diamond Mine 2011 year in review.

[accessed December 19 2012]

www.bhpbilliton.com/home/businesses/diamonds/Documents/EKATI\%20Diamond\%20Mine\%20201 1\%20Year\%20in\%20Review.pdf

Bourdieu, P. 1984. Distinction: a social critique of the judgement of taste. Cambridge MA: Harvard University Press.

Bridge, G. 2008. Global production networks and the extractive sector: governing resource-based development. Journal of Economic Geography 8(3): 389-419.

Cameron, E. 2011. Copper stories: imaginative geographies and material orderings of the Central Canadian Arctic. In A. Baldwin, E. Cameron and A. Kobayashi (eds.) Rethinking the great white North: race, nature and the historical geographies of whiteness in Canada. Vancouver: UBC Press. Pp169-190.

Crate, S. 2006. Cows, kin and globalization: an ethnography of sustainability. New York: Rowman and Littlefield Publishers, Inc.

DeBeers Canada. 2011. Snap Lake Mine. [Accessed December 19 2012] www.debeerscanada.com/files_3/pdf_documents/Snap-Lake-Mine_Fast-Facts.pdf

DeMarco, A. 2012. Harry Winston to purchase Ekati Diamond Mine for \$500 million. Forbes [Accessed December 19 2012] www.forbes.com/sites/anthonydemarco/2012/11/13/harry-winston-to-purchaseekati-diamond-mine-for-500-million/

Desbiens, C. 2004. Producing North and South: a political geography of hydro development in Québec. Canadian Geographer 48(2): 101-117.

Dowsley, M. 2010. The value of a polar bear: evaluating the role of a multiple-use resource in the Nunavut mixed economy. Arctic Anthropology 47(1): 39-56.

Eskimo Diamonds. 2009. Website [accessed July 10 2009]. www.Eskimodiamonds.com 
Ettlinger, N. 2011. Governmentality as epistemology. Annals of the Association of American Geographers 101 (3): 537-560.

Foucault, M. 1995. Discipline and punish: the birth of the prison. New York: Vintage Books.

Foucault, M. 2003. Society must be defended: lectures at the Collège de France, 1975-1976. M. Bertani and A. Fonatana (eds.). New York: Picador.

Goodman, M. 2010. The mirror of consumption: celebritization, developmental consumption and the shifting cultural politics of fair trade. Geoforum 41(1): 104-116.

Guthman, J. 2009. Unveiling the unveiling: commodity chains, commodity fetishism, and the "value" of voluntary, ethical food labels. In J. Bair (ed.) Frontiers of commodity chain research. Stanford: Stanford University Press. Pp190-206.

Hornborg, A. 2007. Introduction: environmental history as political ecology. In A. Hornborg, J.R. McNeill and J. Martinez-Alier (eds.) Rethinking environmental history: World-system history and global environmental change. New York: Altamira Press. Pp1-24.

Huber, M. 2011. Enforcing scarcity: oil, violence and the making of the market. Annals of the Association of American Geographers. 101(4): 816-826.

Jackson, P. 2004. Local consumption cultures in a globalizing world. Transactions of the Institute of British Geographers 29(2): 165-178.

Jackson, P., N. Ward and P. Russell. 2009. Moral economies of food and geographies of responsibility. Transactions of the Institute of British Geographers 34(1): 12-24.

Keeling, A. and J. Sandlos. 2009. Environmental justice goes underground? Historical notes from Canada's northern mining frontier. Environmental Justice 2(3): 117-125.

Kempton, D. and R. Levine. 1995. Soviet and Russian relations with foreign corporations: the case of gold and diamonds. Slavic Review 54(1): 80-110.

Lackenbauer, P. and M. Farish. 2007. The Cold War on Canadian soil: militarizing a northern environment. Environmental History 12(4): 920-950.

Litosseliti, L. 2003. Using focus groups in research. New York: Continuum.

Maple Leaf Diamonds.com. 2010. Website. [accessed March $23 \quad 2010$ ]. www.mapleleafdiamonds.com/mld/index.html

Marston, S., J.P. Jones III, and K. Woodward. 2005. Human geography without scale. Transactions of the Institute of British Geographers 30(4): 416-432.

McPherson, R. 2003. New owners in their own land: minerals and Inuit land claims. Calgary: University of Calgary Press.

Meredith, M. 2007. Diamonds, gold and war: the British, the Boers, and the making of South Africa. New York: Simon and Schuster.

Moore, J. 2007. Silver, ecology, and the origins of the modern world, 1450-1640. In A. Hornborg, J.R. McNeill and J. Martinez-Alier (eds.) Rethinking environmental history: world-system history and global environmental change. New York: Altamira Press. Pp123-142.

Natural Resources Canada. 2011a. Ekati Mine - Northwest Territories: info bulletin. [Accessed December 19 2012] www.nrcan.gc.ca/minerals-metals/aboriginal/bulletin/3719

Natural Resources Canada. 2011b. Diavik Diamond Mine: info bulletin. [Accessed December 19 2012] www.nrcan.gc.ca/minerals-metals/aboriginal/bulletin/3189

NWT Chamber of Mines. 1986a. Letter to The Honourable Bill McNight, P.C., M.P. NWT Archives, Prince of Wales Heritage Center, Yellowknife, NWT. N1999-019 4-13.

NWT Chamber of Mines. 1986b. Aboriginal land claims in the NWT. NWT Archives, Prince of Wales Heritage Center, Yellowknife, NWT. N1999-019 5-4.

Pain, R. 2009. Globalized fear? Towards an emotional geopolitics. Progress in Human Geography 33(4): 466-486.

Panelli, R., P. Hubbard, B. Coombes and S. Suchet-Pearson. 2009. De-centring white ruralities: ethnic diversity, racialisation and indigenous countrysides. Journal of Rural Studies 25(4): 355-364.

Richards, P. 2001. Are "forest" wars in Africa resource conflicts? The case of Sierra Leone. In N. Peluso and M.J. Watts (eds.) Violent Environments. Ithaca, NY: Cornell University Press. Pp 65-82.

Rio Tinto. 2009. Diavik Diamond Mine Factbook. [Accessed December 19 2012] http://www.diavik.ca/documents/diavikfactbook.pdf

Roberts, J. 2003. Glitter and greed: the secret world of the diamond cartel. NewYork: The Disinformation Company.

Schlosser, K. 2013. Regimes of ethical value? Landscape, race and representation in the Canadian diamond industry. Antipode 45(1): 161-179. 
Searles, E. 2006. Anthropology in an era of Inuit empowerment. In P. Stern and L. Stevenson (eds.) Critical Inuit studies: an anthology of contemporary Arctic ethnography. Lincoln: University of Nebraska Press. Pp89-104.

Simpson, P. 2003. From Keswick to Kugluktuk: marketing the (neo)colonial. Canadian Woman Studies 23(1): 90-95.

Smillie, I. 2010. Blood on the stone: greed, corruption and war in the global diamond trade. New York: Anthem Press.

Spar, D. 2006. Continuity and change in the international diamond market. Journal of Economic Perspectives 20(3): 195-208.

Stern, P. 2003. Upside-down and backwards: time discipline in a Canadian Inuit town. Anthropologica 45(1): 147-161.

Stern, P. 2010. Daily life of the Inuit. Denver: The Greenwood Press.

Stevenson, L. 2006. The ethical injunction to remember. In P. Stern and L. Stevenson (eds.) Critical Inuit studies: an anthology of contemporary Arctic ethnography. Lincoln: University of Nebraska Press. Pp168-186.

Tester, F. 2006. Iglu to Iglurjuaq. In P. Stern and L. Stevenson (eds.) Critical Inuit studies: an anthology of contemporary Arctic ethnography. Lincoln: University of Nebraska Press. Pp230-252.

Tester, F. and P. McNicoll. 2004. Isumagijaksaq: mindful of the state: social constructions of Inuit suicide. Social Science and Medicine 58: 2625-2636.

Thompson, E.P. 1967. Time, work-discipline and industrial capitalism. Past and Present 38(1): 56-97.

Thorpe, N., N. Hakongak, S. Eyegetok, and the Kitikmeot Elders. 2001. Thunder on the tundra: Inuit Qaujimajatuqangit of the Bathurst Caribou. Cambridge Bay, Nunavut: Tuktu and Nogak Project.

Trentmann, F. 2006. Knowing consumers - histories, identities, practices: an introduction. In F. Trentmann (ed.) The making of the consumer: knowledge, power and identity in the modern world. Oxford: Berg. Pp1-27.

Vander Kloet, M. 2009. A trip to the co-op: the production, consumption and salvation of Canadian wilderness. International Journal of Canadian Studies 39-40: 231-251.

Wenzel, G. 2004. From TEK to IQ: Inuit Qaujimajatuqangit and Inuit cultural ecology. Arctic Anthropology 41(2): 238-250.

\begin{abstract}
Canadian diamonds are marketed as ethical alternatives to so-called 'conflict diamonds.' This research analyzes a series of focus groups conducted in Kugluktuk, Nunavut, an Inuit town impacted by diamond mining. The article sheds some light on the risks and benefits of mining, but it also examines the broader historical and geographic context of commodity networks for diamonds as an entry point into a critique of the possibility of consumption as ethical praxis. What the analysis shows is that the risks and benefits assessed by focus group participants manifest themselves in a context of colonial dispossession of sovereignty over resources. This dispossession is part of the very process of market regulation that is necessary for capital accumulation. Accumulated capital professes to satisfy this created need ethically. In much of Arctic Canada, for example, this takes the form of a dependency on the market in order to secure the wages now necessary to engage in subsistence activities. The purpose of this article is not to unveil exploitive conditions of production or to claim that Canadian diamonds are in fact unethical, but rather to question what we mean by 'ethical' commodities by examining the claim within a broader historical political ecology.
\end{abstract}

Keywords: Diamonds, political ecology, market regulation, Nunavut, ethical consumption. 


\section{Résumé}

Les diamants canadiens sont commercialisés comme des alternatives éthiques à soi-disant «diamants de la guerre». Cet article analyse quelques groupes de discussion menés avec la population locale a Kugluktuk, au Nunavut, une ville Inuit touchés par les mines de diamants. L'article met en lumière les risques et les avantages de l'exploitation minière, mais il examine aussi le contexte historique et géographique des «commodity networks» pour les diamants. Il est utilisé comme un point d'entrée dans une critique de la possibilité de la consommation comme praxis éthique. Ce que l'analyse montre que les risques et bénéfices évalués par les participants aux groupes de discussion se manifestent dans un contexte de dépossession coloniale de la souveraineté sur les (ou leurs) ressources. Cette dépossession fait partie du processus même de la régulation du marché qui est nécessaire pour l'accumulation du capital. Le capital accumulé professe qu'il est capable de répondre à ce besoin créé dans un façon éthique. Dans une grande partie de l'Arctique canadien, par exemple, cela prend la forme d'une dépendance sur le marché afin de garantir les salaires désormais nécessaires pour s'engager dans des activités de subsistance. Le but de cet article n'est pas de dévoiler des conditions d'exploitation de la production ou de la revendication que les diamants canadiens sont en fait contraires à l'éthique, mais plutôt de s'interroger sur ce que nous entendons par produits «éthiques» par l'examen de la demande dans un large écologie politique avec une approche historique.

Mots-clés: diamants, écologie politique, régulation des marchés, Nunavut, la consommation éthique.

\section{Resumen}

Los diamantes canadienses se comercializan como alternativa ética a los denominados "diamantes de conflicto". Esta investigación analiza una serie de grupos de discusión en Kugluktuk, Nunavut, una ciudad inuit afectada por la minería del diamante. El artículo demuestra los riesgos y beneficios de la minería, pero también examina el más amplio contexto geográfico e histórico de las redes de distribución y consumo de diamantes como punto de entrada a una crítica del consumo como práctica ética. El análisis muestra que los riesgos y beneficios evaluados por los participantes en los grupos de discusión se manifiestan en un contexto de desposesión colonial de la soberanía sobre los recursos. Esta desposesión es parte del proceso mismo de regulación del mercado que es necesaria para la acumulación de capital. El capital acumulado profesa satisfacer éticamente esta necesidad creada. En gran parte de la zona ártica del Canadá, por ejemplo, esto lleva a la dependencia del mercado a fin de asegurar los salarios ahora necesarios para poder llevar a cabo actividades de subsistencia. El propósito de este ensayo no es desvelar condiciones de explotación o afirmar que los diamantes canadienses son en realidad producto no ético, sino más bien cuestionar lo que se quiere decir cuando se habla de materias primas "éticas", mediante el examen de tal afirmación desde una ecología histórica política más amplia.

Palabras clave: diamantes, ecología política, regulación del mercado, Nunavut, consumo ético. 